\title{
Revoking a Decision to Suspend Payment of Disputed Tax "on Further Consideration": An Administrative Law Perspective
}

\section{P.E.R}

Pioneer in peer-reviewed,

open access online law publications

Author

Silke de Lange

Affiliation

Stellenbosch University

South Africa

Email silkeb@sun.ac.za

Date Submission

11 November 2019

Date Revised

2 February 2021

Date Accepted

2 February 2021

Date published

11 February 2021

Editor Prof C Rautenbach

How to cite this article

De Lange S "Revoking a Decision to Suspend Payment of Disputed Tax 'on Further Consideration': An Administrative Law Perspective" PER / PELJ 2021(24) - DOI http://dx.doi.org/10.17159/1727$3781 / 2021 / v 24 i 0 a 7612$

\section{Copyright}

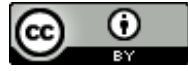

DOI

http://dx.doi.org/10.17159/1727$3781 / 2021 / v 24 i 0 a 7612$

\begin{abstract}
The "pay now, argue later" rule entails that the obligation to pay tax and the right of the South African Revenue Service (SARS) to receive and recover tax are not suspended by objection or appeal. However, in terms of section 164(2) of the Tax Administration Act 28 of 2011 (hereafter TAA), a taxpayer may request a senior SARS official to suspend the payment of disputed tax and a senior SARS official may, in terms of section 164(3) of the TAA, grant such a suspension having regard to certain relevant factors. Section 164(5) of the TAA further provides that the decision to suspend may be revoked on a number of grounds. One of the grounds is when a senior SARS official is satisfied, on further consideration of the factors which had to be taken into account when the suspension was granted, that the suspension should not have been granted. There is no indication in the TAA that this ground for revoking the suspension requires that there should be a material change in the factors, as this is provided for in a separate ground to revoke the decision to suspend the payment of disputed tax. It is also not required, for example, that the taxpayer should have failed to disclose information when making the request to suspend the payment. It is argued in this article that the ground for revoking a decision to suspend payment "on further consideration of the factors" raises concerns from an administrative law point of view. This is based on the revocation being an "administrative action" as contemplated in section 33 of the Constitution of the Republic of South Africa, 1996 read together with the Promotion of Administrative Justice Act 3 of 2000, which requires that the revocation should be lawful, reasonable and procedurally fair. The concerns raised in this article relate not only to the rights of taxpayers, but also to the duties of the SARS officials revoking a decision to suspend payment as it is equally important that administrators should be able to know how and when to act in a manner which is lawful, reasonable and procedurally fair.
\end{abstract}

\section{Keywords}

Tax administration; Tax Administration Act; pay now argue later; suspension of payment of disputed tax; administrative action; revoking a decision; functus officio. 


\section{Introduction}

Section 164 of the Tax Administration Act 28 of 2011 (hereafter TAA) deals with the payment of tax pending objection or appeal. It contains the socalled "pay now, argue later"1 rule. The rule entails that, unless a senior South African Revenue Service (SARS) official otherwise directs, the obligation to pay and the right of SARS to receive and recover the tax will not be suspended (i) by an objection against an assessment or decision, (ii) by an appeal against an assessment or decision to the tax board or the tax court, or (iii) pending a decision of a court of law pursuant to an appeal against a decision of the tax court. ${ }^{2}$

Whilst the payment of tax pending an objection or appeal is generally not suspended, a senior SARS official has the power to suspend the payment of disputed tax, or a portion thereof, in accordance with section 164(3) of the TAA, upon the request of a taxpayer in terms of section 164(2) of the TAA. Paragraphs (a) - (e) of section 164(3) of the TAA contain the listed factors to be considered by the senior SARS official when making a decision to suspend the payment of disputed tax. The senior SARS official must consider these listed factors, but other factors may also be taken into account. $^{3}$

Once a decision has been taken by a senior SARS official to suspend the payment of disputed tax in terms of section 164(3) of the TAA, section 164(5) of the TAA allows a senior SARS official to revoke such a decision to suspend payment with immediate effect if satisfied that:
(a) after the lodging of the objection or appeal, the objection or appeal is frivolous or vexatious;
(b) the taxpayer is employing dilatory tactics in conducting the objection or appeal;

\footnotetext{
Silke de Lange. BAccLLB MComm (Taxation) (US). Lecturer, Department of Mercantile Law, University of Stellenbosch, South Africa. Email: silkeb@sun.ac.za. ORCiD ID: https://orcid.org/0000-0003-3939-5209.

1 See, for example, Croome and Olivier Tax Administration 371; Commissioner for SARS v Miles Plant Hire (Pty) Ltd 76 SATC 1 para 11.

2 Section 164(1) of the Tax Administration Act 28 of 2011 (TAA), read together with ss 104,107 and 133.

3 Section 164(3) of the TAA states that payment may be suspended "having regard to relevant factors, including..." which indicates that at least the listed factors must be taken into account by the senior SARS official. This view is supported by Croome and Olivier Tax Administration 379, where it is stated that "SARS needs to consider the factors stated in $\mathrm{s} 164$ and may also take account of other factors which are not stated in the section." Also see SARS Short Guide to the TAA, 201161 where it is stated that "[t]he five factors that must be taken into account by the senior SARS official are..." listing paragraphs (a)-(e) of s 164(3) of the TAA.
} 
(c) on further consideration of the factors referred to in subsection (3), the suspension should not have been given; or

(d) there is a material change in any of the factors referred to in subsection (3), upon which the decision to suspend payment of the amount involved was based.

Without reference to any authority such as section 164(5) of the TAA, the SARS Dispute Resolution Guide provides that the decision to suspend may be reviewed and withdrawn by SARS against the following factors: "the original circumstances, the taxpayer's current circumstances, the merits of an objection or appeal." 4 It is submitted that there is, however, no legal basis for such an authorisation on the factors mentioned apart from the grounds for a revocation provided for in section 164(5) of the TAA, as set out above.

The use of "if satisfied that" in section 164(5) of the TAA confers a subjective discretion on the senior SARS official to revoke a decision to suspend payment. ${ }^{5}$ The grounds for a revocation listed in paragraphs (a) and (b) of section 164(5) of the TAA (when there is a frivolous objection or appeal, a vexatious objection or appeal or when the taxpayer is employing delaying tactics) are justifiable (and this could perhaps also relate to the merits referred to in the SARS Dispute Resolution Guide mentioned in the paragraph above). A taxpayer should not be able to abuse a request for a suspension by having an ulterior motive. Croome and Olivier argue that these grounds are "to prevent taxpayers from filing objections that are without substance" and to prevent taxpayers from delaying the payment of tax that is lawfully due to SARS. ${ }^{6}$ Furthermore, the ground for a revocation in paragraph (d) of section 164(5) of the TAA (hereafter paragraph (d)) is sensible in principle, as a change in circumstances could result in a different outcome (and this could perhaps also relate to the original and current circumstances referred to in the SARS Dispute Resolution Guide mentioned in the paragraph above). It should be noted that section 164(4) of the TAA also contains grounds for a revocation if, for example, after payment was suspended, no objection is lodged or if no appeal is lodged after an objection was disallowed. ${ }^{7}$ These grounds are also not considered as problematic for the purposes of this article.

SARS Dispute Resolution Guide, 202023.

Hoexter Administrative Law 299.

Croome and Olivier Tax Administration 381.

Section 164(4) of the TAA reads as follows: "If payment of tax was suspended under subsection (3) and subsequently (a) no objection is lodged; (b) an objection is disallowed and no appeal is lodged; or (c) an appeal to the tax board or court is unsuccessful and no further appeal is noted, the suspension is revoked with immediate effect from the date of the expiry of the relevant prescribed time period or any extension of the relevant time period under this Act." 
What is argued in this article, however, is that paragraph (c) of section 164(5) of the TAA (hereafter paragraph (c)) raises concerns, both for the taxpayer and for the senior SARS official revoking the decision based on this ground. It allows a senior SARS official to revoke a decision to suspend payment with immediate effect if satisfied that on further consideration of the factors referred to in subsection (3), the suspension should not have been given. Paragraph (c) does not expressly require that there must have been a change in circumstances, as this is provided for in paragraph (d) as a separate ground for revocation. It also does not require, for example, that the taxpayer did not make a proper disclosure of the relevant facts. Paragraph (c) therefore provides no guidance for either the taxpayer or the senior SARS official regarding how and when the decision to grant the suspension can or must be revisited. Paragraph (c) further seems to suggest that the initial decision to grant the suspension was not properly considered, and that a proper reconsideration, for no particular reason such as a change in circumstances, now results in a different outcome, which requires a revocation. ${ }^{8}$

Croome and Olivier seem to approve its validity by interpreting paragraph (c) as follows:

\begin{abstract}
SARS is entitled to reconsider the criteria stated in s 164(3) and if that review indicates that the suspension should not been [sic] approved at the outset, SARS may withdraw that approval. ${ }^{9}$
\end{abstract}

The constitutional validity of paragraph (c) has, however, not yet been expressly tested by our courts. Even if it is assumed that section 164 of the TAA is constitutionally valid, the decisions taken in terms of section 164, including the decision to suspend the payment and the revocation thereof, can still be challenged by a taxpayer. ${ }^{10}$ Accordingly, it will be considered in this article whether such a revocation based on the ground in paragraph (c) can meet the requirements of just administrative action as required by section 33 of the Constitution of the Republic of South Africa, 1996 (the Constitution). The right to just administrative action is relevant as the decision to suspend the payment, which is now being revoked, amounts to administrative action in terms of section 33 of the Constitution, read together with the Promotion of Administrative Justice Act 3 of 2000 (hereafter PAJA). ${ }^{11}$ Without a more detailed analysis, therefore, for the purposes of this article it will be assumed that the decision to revoke the suspension of payment is also administrative action. ${ }^{12}$ Section 33 of the Constitution

De Lange and Van Wyk 2017 PELJ 9.

Croome and Olivier Tax Administration 381.

Croome and Olivier Tax Administration 375.

De Lange and Van Wyk 2017 PELJ 3, specifically fn 8.

Briefly, $\mathrm{s} 1$ of the Promotion of Administrative Justice Act 3 of 2000 (PAJA) defines "administrative action" as "any decision taken, or any failure to take a decision, by 
requires that administrative action must be lawful, reasonable and procedurally fair. These requirements therefore apply to the decision to suspend payment in terms of section 164(3) of the TAA, and to the decision to revoke the aforementioned decision in terms of paragraph (c). ${ }^{13}$ The focus of this article will be on this latter decision to revoke in terms of paragraph (c).

In order to put the current paragraph (c) into perspective, a brief historical and comparative analysis follows.

\section{Brief historical and comparative perspective}

\subsection{Income Tax Act and Value-Added Tax Act}

Prior to the commencement of the TAA on 1 October 2012, the "pay now, argue later" rule was contained in section 88 of the Income Tax Act 58 of 1962 and section 36 of the Value-Added Tax Act 89 of 1991 (hereafter VAT Act).

In the case of Capstone 556 (Pty) Ltd v Commissioner for SARS (hereafter the Capstone case),${ }^{14}$ the court considered a previous version of the "pay now, argue later" rule as contained in section 88 of the Income Tax Act at the time. The suspension of payment granted by SARS was made subject to a condition that it might "be reviewed at any time". ${ }^{15}$ Section 88 of the Income Tax Act (at the time) did not include revocation powers, similar to section 164(5) of the TAA. The court therefore had to consider whether the Commissioner was allowed to attach the condition to review the suspension at any time to the granting of the suspension. ${ }^{16}$ This required a determination of whether section 88 (at the time) impliedly authorised the Commissioner to review and revoke the suspension. ${ }^{17}$ The court stated as follows in respect of the "direction" of the Commissioner to suspend the payment:

I can think of no reason why the content of the direction should not include a reservation of the right to revisit its terms; particularly having regard to the factors that would have to weigh with the Commissioner in determining it. Having regard to the recognised public policy considerations underpinning the 'pay now, argue later' policy, the Commissioner would,

an organ of state, when... exercising a public power or performing a public function in terms of any legislation... which adversely affects the rights of any person and which has a direct, external legal effect". The exclusions listed in the definition are not relevant. Furthermore, the definition of "decision" in s 1 of PAJA clearly includes a revocation. For a detailed discussion of the right to just administrative action in the context of the decision to suspend the payment, see De Lange and Van Wyk 2017 PELJ.

14 Capstone 556 (Pty) Ltd v Commissioner for SARS 74 SATC 20 (the Capstone case).

15 Capstone case para 18.

$16 \quad$ Capstone case para 42.

$17 \quad$ Capstone case para 42. 
for instance, obviously need to be able to revise a decision to direct that the obligation to pay be suspended if it became evident to him in the period before the appeal was heard that the taxpayer's financial situation was deteriorating thereby jeopardising the prospect of making a recovery if the appeal were determined against the taxpayer. Similarly, the efficacious operation of the statute would be thwarted if the Commissioner were unable to revoke a decision to direct that a taxpayer's obligation to pay be suspended by the noting an appeal if it became apparent that the taxpayer was failing conscientiously to prosecute the appeal. ${ }^{18}$

Whilst the court therefore clearly acknowledges in the Capstone case that there is a need for the power to revoke such a decision, the two grounds found in the paragraph quoted above are (i) a change in circumstances ("the taxpayer's financial situation was deteriorating") and (ii) if the taxpayer fails to lodge an appeal (for example, after an objection was disallowed). These powers to revoke are dealt with in section 164(5)(d) and section 164(4)(b) of the TAA respectively.

The court also confirms in the Capstone case that such a later decision to revoke would have to be in compliance with administrative justice. ${ }^{19}$ However, the court concludes as follows:

\begin{abstract}
The achievement of the object [efficacious tax recovery] would be frustrated if the Commissioner's power to grant a dispensation relieving the taxpayer from the undeniably rigorous effect of the provision did not include the right to make the grant of the dispensation subject to appropriate conditions and even revocation, including in a case in which it subsequently appeared, on a reconsideration of the relevant material, that it had not been appropriate, after all, to have given the dispensation in the first place. ${ }^{20}$
\end{abstract}

The reference to a "reconsideration" and the statement that the decision should not have been given in the first place seem to suggest that the court approves a provision such as paragraph (c) (which did not yet exist at the time of the decision). This proposition will be challenged in this article, however.

As stated above, the version of the "pay now, argue later" rule considered by the court in the Capstone case did not include a ground for revoking a decision to suspend "on further consideration". However, at the time of the repeal of section 88 of the Income Tax Act and section 36 of the VAT Act by the TAA, ${ }^{21}$ there was an almost identical ground for revoking a decision to suspend payment (if compared to the current paragraph (c)) in section

Capstone case para 43.

Capstone case para 44.

Capstone case para 45.

Section 271, read together with Schedule 1, of the TAA repealed s 88 of the Income Tax Act 58 of 1962 (the Income Tax Act) and s 36 of the Value-Added Tax Act 89 of 1991 (the VAT Act). 
88(4)(c) of the Income Tax Act and section 36(4)(c) of the VAT Act. ${ }^{22}$ This ground for revoking a decision to suspend payment continues to exist in the TAA.

The Memorandum on the Objects of the Tax Administration Bill, 2011 stated as follows regarding the rationale for tax administration review in South Africa at the time:

The current administrative provisions in tax legislation are outdated. Although the provisions have been amended over the years, the tax Acts have become fragmented and disparate provisions arose in the different tax Acts. The current framework is outdated and needs to be aligned with modern approaches, business practices, accounting practices and constitutional rights. ${ }^{23}$

It can be deduced from the fact that this specific ground for revoking the decision to suspend payment was retained in an almost identical form in paragraph (c), that it was not regarded by the legislature as being a problematic provision, in the light thereof that the TAA was aimed at aligning tax legislation with constitutional rights. Even though section 164(5) of the TAA has been amended twice since its commencement, such amendments were insignificant and did not relate to paragraph (c). ${ }^{24}$ Whilst it is clear that section 164(5) of the TAA has not been left unnoticed, no attempt has been made to amend or remove paragraph (c) since the TAA came into operation. To the contrary, a relatively new piece of legislation in the context of customs and excise even has a similar provision when compared to paragraph (c) (see paragraph 2.2 below). This seems to suggest that a senior SARS official's decision to revoke a suspension should be able to meet the requirements of lawful, reasonable and procedurally fair administrative action.

Section 88(4)(c) of the Income Tax Act read as follows: "The Commissioner may deny a request in terms of subsection (3) or revoke a decision to suspend payment in terms of that subsection with immediate effect whenever he or she is satisfied that- ... (c) on further consideration of the factors contemplated in subsection (3), the suspension should not have been given...". Section 36(4)(c) of the VAT Act reads as follows: "The Commissioner may deny a request in terms of subsection (3) or revoke a decision to suspend payment in terms of that subsection with immediate effect whenever he or she is satisfied that-... (c) on further consideration of the factors contemplated in subsection (3), the suspension should not have been given...".

SARS 2011 https://www.sars.gov.za/AllDocs/LegalDoclib/ExpIMemo/LAPD-LPrepEM-2011-03\%20-

\%20Memorandum\%20Objects\%20Tax\%20Administration\%20Bill\%202011.pdf

(Memorandum on the Objects of the Tax Administration Bill, 2011) 178.

24 Section 164(5) of the TAA was amended by s 64 of the Tax Administration Laws Amendment Act 21 of 2012 and s 58 of the Tax Administration Laws Amendment Act 39 of 2013. The first amendment added the words "payment of" in paragraph (d) and the second amendment added a reference to subsection (3) in paragraph (d). 
Lastly it remains to mention that whilst the Constitutional Court upheld the constitutional validity of the "pay now, argue later" rule in section 36(1) of the VAT Act in Metcash Trading Ltd v Commissioner for SARS, ${ }^{25}$ this does not mean that paragraph (c) or a revocation in terms thereof is constitutionally valid.

\subsection{Customs and Excise Act and Customs Control Act}

The TAA applies only to "tax Acts", and in section 1 of the TAA customs and excise legislation is expressly excluded from the definition of a "tax Act". ${ }^{26}$ Section 164 of the TAA is therefore not applicable in the customs and excise context. However, section 77G of the Customs and Excise Act 91 of 1964 currently contains the "pay now, argue later" rule in this context. It provides that the Commissioner of SARS may suspend payment of tax, but it does not contain grounds for revocation as found in section 164(5) of the TAA. Section 77G of the Customs and Excise Act will, however, be repealed once the new Customs Control Act 31 of 2014 comes into operation (which date must still be proclaimed). ${ }^{27}$ Section 830 of the Customs Control Act will contain the "pay now, argue later" rule in future. Without dealing with this section in further detail, it can be concluded that section 830(5)(c) of the Customs Control Act contains a ground almost identical to the ground for revocation in paragraph (c). Section 830(5)(c) of the Customs Control Act provides as follows: ${ }^{28}$

The customs authority may at any time withdraw a suspension or deferment granted to a person in terms of this section ... (c) if on further consideration of the factors referred to in subsection (4), the suspension or deferment should not have been granted ... .

As the Customs Control Act is a more recent piece of legislation than the TAA, it affirms that the inclusion of a ground to withdraw or revoke a decision to suspend payment if, on further consideration of the factors, the suspension should not have been given or granted, deliberately remains on the statute book.

\subsection{Tax Administration Act}

In the TAA itself, the phrase "on further consideration" appears only in section $164(5)$. Even though section 164 of the TAA is the only section of

25 Metcash Trading Ltd $v$ Commissioner for SARS 63 SATC 13. A similar constitutional challenge to the previous s 88 of the Income Tax Act or the current s 164 of the TAA has never been brought to the courts.

26 See ss $2-4$ of the TAA.

$27 \quad$ Sections 68 and 88 of Customs and Excise Amendment Act 32 of 2014.

28 A difference between s 164(5)(c) of the TAA and s 830(5)(c) of the Customs Control Act 31 of 2014 (the Customs Control Act) is that the TAA uses the term "revoke" whereas the Customs Control Act refers to "withdraw". It is submitted that revoking and withdrawing should be interpreted as meaning the same in this context. 
the TAA which allows a decision to be revoked, there are numerous other instances in the TAA allowing for a withdrawal. "Withdraw" is defined in the Oxford English Dictionary as "retract, revoke, rescind", and therefore, revoke and withdraw can be regarded as meaning the same in this context. However, an analysis of the instances in the TAA allowing for a withdrawal by SARS (and not, for example, by the court or the taxpayer) shows that a withdrawal always falls in either one of the following categories:

(i) Objective, justifiable and rational grounds for a withdrawal are provided. ${ }^{29}$

(ii) The taxpayer failed to disclose a material matter. ${ }^{30}$

(iii) The withdrawal is to the taxpayer's benefit. ${ }^{31}$

(iv) SARS must provide notice of the proposed withdrawal and a reasonable opportunity to object thereto. ${ }^{32}$

The power to revoke in terms of paragraph (c) cannot be classified in any one of the above categories. The conclusion is that paragraph (c) is therefore an exceptional and unusual provision in the TAA. The question is now: Why is paragraph (c) problematic?

\section{Concerns regarding the revocation when, on further consideration, the suspension should not have been given}

As mentioned in paragraph 1 above, it is argued that paragraph (c) (like paragraph (c) of section $830(5)$ of the Customs Control Act ${ }^{33}$ is problematic,

29 For example, SARS may withdraw an assessment in terms of $s$ 98(1) of the TAA if it was issued to the incorrect taxpayer. This is similar to the grounds found in paras (a), (b) and (d) of s 164(5) of the TAA. The same applies to a withdrawal of SARS' approval of an individual representative of a company in terms of $s$ 246(7) of the TAA, on the ground that a person is no longer suitable to represent the company as public officer. See also s 195(3) of the TAA. For example, voluntary disclosure relief may be withdrawn in terms of $s$ 231(1)(a) of the TAA on this basis.

31 For example, SARS may withdraw a certified statement setting out the amount of tax payable and certified by SARS as correct, as part of an application for civil judgment in terms of $s$ 176(1) of the TAA. This is also a withdrawal which can be requested by the taxpayer (and is therefore to the taxpayer's benefit) in terms of $s$ 176(3) of the TAA. This category also similarly applies to a withdrawal of a third-party appointment in terms of $s 179(2)$ of the TAA, which is to the benefit of the third party. For example, an advance ruling may be withdrawn on this basis in terms of $s$ 86(2) of the TAA.

33 For purposes of this article, the focus will only be on s 164(5)(c) of the TAA, and not on s $830(5)(c)$ of the Customs Control Act. However, the same arguments can be made regarding this similar provision in the Customs Control Act. 
both for the taxpayer and for the senior SARS official revoking the decision based on this ground. It has been held by our courts in a tax context that finality and certainty should be upheld in order to avoid arbitrariness. ${ }^{34}$ The question is, however, to what extent a taxpayer is able to rely on finality and certainty, once the decision was taken to suspend payment, if a senior SARS official is allowed to further consider the factors referred to in section 164(3) of the TAA, and to conclude that the suspension should not have been given. Would such a decision by a senior SARS official to revoke not be arbitrary?

It should therefore be considered when and how a senior SARS official's decision to revoke a suspension on this ground in paragraph (c) would meet the requirements of lawful, reasonable and procedurally fair administrative action. Some concerns relating to each of these requirements for just administrative actions are highlighted in this paragraph 3. In addition, concerns are raised in respect of a taxpayer's right to request reasons. ${ }^{35}$

\subsection{Lawfulness}

Lawfulness requires, in basic terms, that the "administrative action and the authorisation for that action must be aligned". ${ }^{36}$ This requires, for example, that the person acting must have been authorised to act. The question of when, if ever, an administrator has the authority to revoke a decision should be considered with reference to the functus officio doctrine. ${ }^{37}$ Even though the common law functus officio doctrine has not been included in PAJA, it remains part of South African administrative law ${ }^{38}$ and some aspects of the doctrine require attention in the context of a revocation in terms of paragraph (c). Thereafter, the requirements of paragraph (c) that the revocation must be done by a senior SARS official and "on further consideration" will be considered, specifically by comparing the grounds for revocation in paragraphs (c) and (d).

\subsubsection{Functus officio}

The functus officio doctrine entails that once a decision has been taken (for example, granting a suspension of payment in terms of section 164(3) of the TAA), it is not possible for the decision-maker "to change his mind and revoke, withdraw or revisit the decision". ${ }^{39}$ Alternatively stated, the decision-

\footnotetext{
34 Carlson Investments Share Block (Pty) Ltd v Commissioner for SARS 63 SATC 295 307.

35 In terms of s 33(2) of the Constitution of the Republic of South Africa, 1996 (the Constitution), read together with s 5 of PAJA.

36 Quinot Administrative Justice 120.

37 Hoexter Administrative Law 276.

$38 \quad$ Pretorius Functus Officio Doctrine 32.

$39 \quad$ Hoexter Administrative Law 277.
} 
maker has "discharged his office". ${ }^{40}$ According to Hoexter, this is necessary to achieve certainty, fairness and legality, and to protect individuals from "injustice that would result from a sudden change of mind" of the administrator. ${ }^{41}$ In a tax context, taxpayers should be able to rely on decisions taken by SARS because otherwise, "intolerable uncertainty would result" if decisions could be changed at any time. ${ }^{42}$

The doctrine requires a final decision, ${ }^{43}$ and it is submitted that the decision in terms of section 164(3) of the TAA to suspend payment is a final decision as it is administrative action that is subject to judicial review in terms of section 6 of PAJA. ${ }^{44}$ Furthermore, the doctrine is not absolute and allows for exceptions, for example, should the legislation allow the decision-maker to alter or rescind his or her decision. ${ }^{45}$ Section $164(5)$ of the TAA can be seen as a typical example of such an exception to the functus officio doctrine, providing a senior SARS official with statutory authority to revoke a decision to suspend payment. Even though exceptions to functus officio are allowed, the question remains whether an exception in the form of a statutory power to revoke is constitutional. ${ }^{46}$ Essentially, the legislature's power to allow for revocation in legislation is not "boundless". ${ }^{4}$ In this regard, Hoexter states that the power to revoke may not be "unlimited or too extensive". ${ }^{48}$ Pretorius is of the view that the power to revoke or vary may not be "unrestricted" and that it is subject to the limitations, circumstances and conditions provided for in the legislation. ${ }^{49}$

The exceptions to the functus officio doctrine require a balance between flexibility (for SARS) and finality and certainty (for the taxpayer). ${ }^{50}$ It is submitted that a revocation "on further consideration" in terms of paragraph (c) is arguably "unlimited or too extensive" as no limitations, circumstances, conditions, guidance, factors, grounds etcetera are provided which would require or justify a further consideration of the factors referred to in section 164(3) of the TAA.

Baxter discusses the variation or revocation of favourable decisions when expressly authorised or empowered, of which a revocation in terms of paragraph (c) would be an example, prior to the Constitution and PAJA. ${ }^{51}$

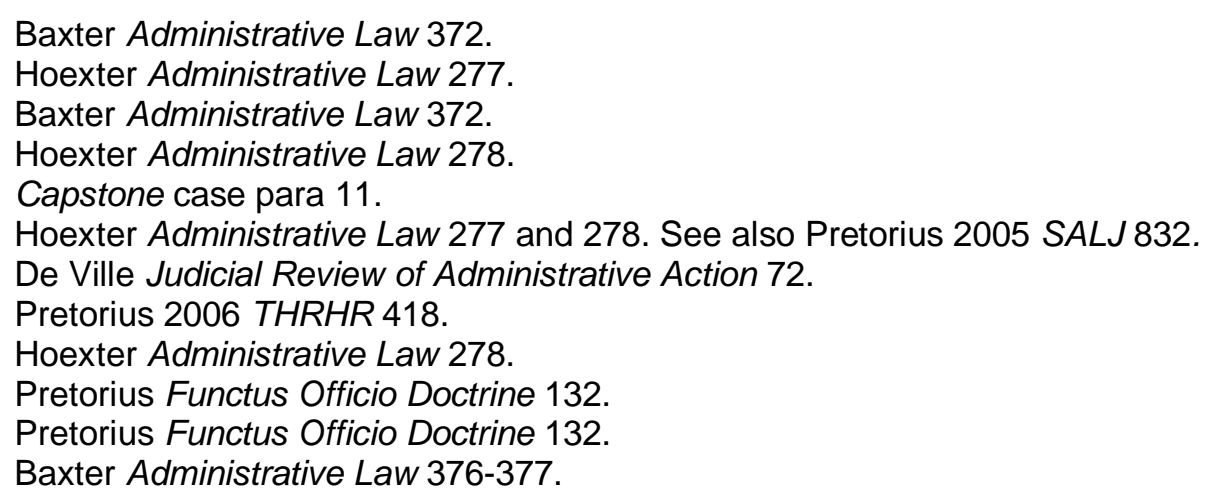


The circumstances mentioned by Baxter which could warrant a variation, revocation, withdrawal, suspension, cancellation etcetera are: (i) if it is "in the interest of public health or safety", (ii) when conditions attached to a decision are not complied with, (iii) "if false information was presented when application was made" or (iv) where decisions were based on "errors which were within the decision-maker's discretionary powers". ${ }^{52}$ It can be assumed that public health or safety are not relevant in this tax context, that the conditions attached to a suspension of payment are complied with (if conditions are at all allowed to be attached to it) and that no false information was presented when the taxpayer applied for the suspension of payment. This leaves the last mentioned circumstance as the only possible ground that a revocation in terms of paragraph (c) could be classified as, i.e. when the senior SARS official granted the suspension based upon errors, if such errors were within the discretionary powers of the senior SARS official. Baxter submits that a revocation in such circumstances could result in severe injustice, and that a decision based on such errors should therefore be changed in only two circumstances. ${ }^{53}$ Firstly, when the person affected requests that the decision should be withdrawn or secondly, if it is "absolutely essential to the public interest". ${ }^{54}$ It can be assumed that a taxpayer is unlikely to request that the decision to suspend payment should be revoked. Therefore, according to the circumstances identified by Baxter, a revocation in terms of paragraph (c) would be allowed only if the decision to grant the suspension was based upon errors within the decision-maker's discretionary powers and if the revocation of the suspension is necessitated by public interest.

Reference to the public interest in the context of revoking a decision was also made by the court in the case of Carlson Investments Share Block (Pty) Ltd $v$ Commissioner for SARS, which is a post-Constitution case on reconsidering a tax assessment. ${ }^{55}$ It was held that decisions can be revisited (here revising an assessment) only if provided for in the statute and if it is required "in the public interest and in the interests of justice". ${ }^{56}$ Pretorius states that this case has the implication that a revocation power would be in breach of section 33 of the Constitution if it allows "arbitrary or capricious behaviour". ${ }^{57}$ In order to determine the constitutional validity of revocation powers, factors such as whether the revocation is limited to a certain time period, the requirements for a revocation and that it must be exercised in

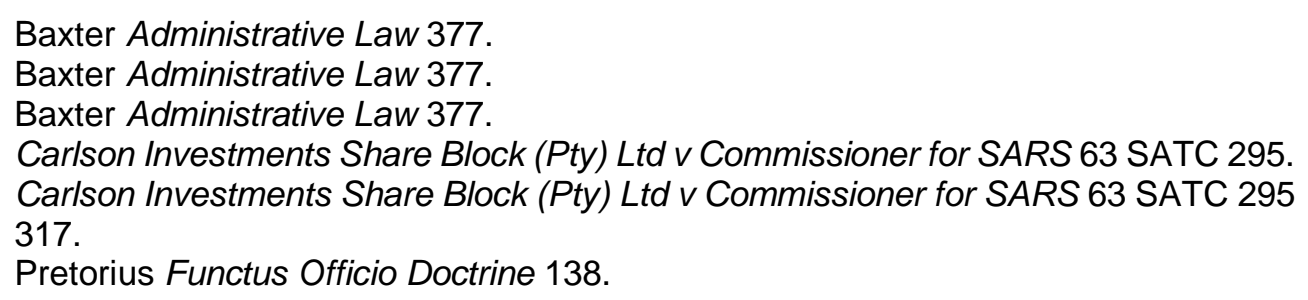


the public or national interest should be taken into account. ${ }^{58}$ The last mentioned would be a balancing exercise as the public interest to revoke "should outweigh the individual's interest in finality and certainty". 59

A revocation in terms of section 164(5) of the TAA has no time limits attached to it, nor does paragraph (c) have any requirements to revoke. When our courts would regard a revocation in terms of paragraph (c) to be in the public interest and in the interests of justice remains to be seen. It is therefore not clear that the exception to the functus officio doctrine as found in paragraph (c) is constitutionally valid. As no conditions under which a revocation may take place are provided in paragraph (c), a decision taken in terms thereof can be regarded as arbitrary and against the interest of legal certainty. ${ }^{60}$

A possible application of paragraph (c) as a valid exception to the functus officio doctrine is provided in paragraph 3.1 .3 below, together with suggestions to amend the legislation in paragraph 4 below.

\subsubsection{A senior SARS official}

A fundamental requirement of lawfulness is that the decision must have been taken by an authorised person. ${ }^{61}$ Section 6(2)(a)(i) of PAJA allows for the judicial review of administrative action (such as a revocation) if the administrator who took it was not authorised to do so by the empowering provision.

In this regard, section 164(5) of the TAA does not make it clear that the decision to revoke the suspension must be taken by the same senior SARS official as the one who took the decision in terms of subsection (3) to grant the suspension. Subsection (5) refers merely to "a senior SARS official". A senior SARS official acting in terms of subsection (5) must be satisfied "on further consideration of the factors referred to in subsection (3)" that the suspension should not have been given. It is argued that subsection (5) allows for an interpretation that a senior SARS official other than the one who granted the suspension could revoke the suspension.

The exceptions to the functus officio doctrine usually require that the variation or revocation must be done by "the original administrator or by a higher authority". ${ }^{62}$ In the context of a section 164(5)-revocation, the original administrator would be the senior SARS official who granted the suspension

Pretorius Functus Officio Doctrine 138.

Pretorius Functus Officio Doctrine 139.

De Ville Judicial Review of Administrative Action 73.

Quinot Administrative Justice 129.

Hoexter Administrative Law 278. 
in terms of section 164(3) of the TAA, whereas a higher authority could be the Commissioner.

Two questions emerge from this: Firstly, can a decision to withdraw the suspension be taken by another senior SARS official and secondly, can a decision to withdraw the suspension be taken by the Commissioner? Without addressing these questions further, ${ }^{63}$ and even if they should result in an affirmative outcome, it is submitted that the revocation in terms of paragraph (c) should be done by the same person as the one who suspended the payment in terms of section 164(3) of the TAA. This would avoid lawfulness challenges relating to the person exercising the power to revoke.

\subsection{3 "On further consideration of the factors"}

The senior SARS official must be satisfied in terms of paragraph (c) that the suspension should not have been given "on further consideration of the factors referred to in subsection (3)". As lawfulness requires alignment between the decision and its authorisation, the meaning of being satisfied "on further consideration of the factors referred to in subsection (3)" is important. ${ }^{64}$ It is not clear what "further consideration" entails. ${ }^{65}$ As mentioned earlier, paragraph (c) does not expressly require that there must have been a change in circumstances, as this is provided for in paragraph (d) as a separate ground for revocation. Paragraph (c) also does not require, for example, that the taxpayer did not make a proper disclosure of the relevant facts or misrepresented information. If it is assumed that no false information was presented when the taxpayer applied for the suspension of payment, does it mean that the same information can simply be reconsidered at any point in time for any reason in terms of paragraph (c), or is there another possible interpretation, taking into account that paragraph (d) refers to a material change in any of the factors referred to in subsection (3)?

63 This would require a detailed analysis of $s 9$ of the TAA, to determine whether a reference there to a withdrawal of "a decision made by a SARS official" would include a revocation of the decision to suspend payment, which was made by a senior SARS official. Furthermore, s 6(3) of the TAA on the powers and duties required to be exercised by a senior SARS official would also have to be analysed and applied in the context of the revocation. An analysis thereof falls beyond the scope of this article.

64 If a mandatory and material procedure or condition prescribed by an empowering provision was not complied with, or if the action was taken because irrelevant considerations were taken into account or relevant considerations were not considered, the administrative action is reviewable in terms of ss 6(2)(b) and $6(2)(\mathrm{e})(\mathrm{iii})$ of PAJA respectively.

65 It is noted that the concept of "further consideration" does not appear elsewhere in the TAA. 
Paragraph (d) allows for a revocation only if two requirements are met: (i) There was a material change in any of the factors referred to in subsection (3) and (ii) the decision to suspend the payment of the amount involved was based on such a changed factor. Therefore, if there is a material change in respect of a factor upon which the decision to suspend was not based, paragraph (d) would not be applicable. In these very limited circumstances, there is a lacuna in section 164(5) of the TAA. Paragraph (c) could then be relied upon by the senior SARS official as a ground for revocation if there is a material change in respect of a factor upon which the decision to suspend was not based.

It is acknowledged that the list of factors in section 164(3) of the TAA is not a closed list, ${ }^{66}$ and as such, other factors in addition to the factors listed in paragraphs (a) - (e) could be regarded as relevant for the purposes of suspending payment. Utilising paragraph (c) for a revocation as mentioned above requires that the reference in paragraph (c) to "the factors referred to in subsection (3)" refers not only to the factors listed in paragraphs (a) - (e) but refers to all the relevant factors which must be taken into account.

Therefore, and as illustrated by the example below and for purposes of the suggested application of paragraph (c), the material change in respect of a factor upon which the decision to suspend was not based can be only in respect of a relevant factor which is not listed in section 164(3)(a) - (e) of the TAA. ${ }^{67}$ This is concluded based on the following reasoning, with reference to table 1 below. Assume that a taxpayer lodges an objection and a decision was taken to suspend the payment of disputed tax having regard to relevant factors, including that the recovery of the disputed tax will not be in jeopardy or there will be no a risk of the dissipation of assets, the compliance history of the taxpayer with SARS is good, fraud is not prima facie involved in the origin of the dispute, payment will result in irreparable hardship to the taxpayer not justified by the prejudice to SARS or the fiscus if the disputed tax is not paid or recovered and the taxpayer has tendered adequate security for the payment of the disputed tax and accepting it is in the interest of SARS or the fiscus. In other words, all the listed factors count in the taxpayer's favour to suspend the payment and the suspension is based thereon (see column 2 of table 1 below).

Subsequently (see scenario A in column 3 of table 1 below), whilst SARS is considering the objection, and due to developments, there is now a risk of

66 See, for example, Croome and Olivier Tax Administration 379 and Van Wyk and Van Zyl 2016 JEF 564.

67 Paragraphs (f), (g) and (h) of $\mathrm{s} 164(3)$ of the TAA are no longer in operation. These paragraphs were deleted by the Tax Administration Laws Amendment Act 44 of 2014. S 164(3) currently includes only paras (a) to (e); hence, only these factors are addressed. 
the dissipation of assets. This could allow a senior SARS official to revoke a decision to suspend the payment in terms of section 164(5)(d) of the TAA if the senior SARS official is satisfied that there is a material change in factor (a) (namely there is now a risk of the dissipation of assets), and the decision to suspend was initially based on the fact that there was no risk of the dissipation of assets (see column 5 of table 1 below). As a decision to suspend will always require a consideration of at least the listed factors, ${ }^{68} \mathrm{a}$ change in any of those listed factors will be a factor upon which the decision to suspend was based as contemplated in section 164(5)(d) of the TAA. If the factors in paragraphs (a) - (e) must be taken into account, the decision to suspend will inevitably be based on those listed factors, irrespective of their favourable or unfavourable effect on the outcome of allowing the suspension.

Assume that, in another scenario (see scenario B in column 4 of table 1 below), after the suspension has been granted, the taxpayer is not cooperating with the objection, for example, by not delivering documents where SARS requested supporting documents under rule 8 of the Rules promulgated under section 103 of the TAA. ${ }^{69}$ This fact of non-cooperation did not exist at the time the decision to suspend was taken. Should this noncooperation be a reason for not having given the suspension, the ground of revocation in paragraph (c) could arguably be relied upon by the senior SARS official (see column 5 of table 1 below). This could be seen as an example of a material change in respect of a factor upon which the decision to suspend was not initially based, as that factor did not exist, and was not relevant or applicable when the request to suspend payment was initially considered. This means that paragraph (d) is not applicable as it is not "a material change in any of the factors referred to in subsection (3), upon which the decision to suspend payment of the amount involved was based", but it may a material change which requires the senior SARS official to revoke the decision to suspend. If the senior SARS official is not satisfied that the objection if frivolous or vexatious, or that the non-cooperation is a dilatory tactic, ${ }^{70}$ paragraph (c) is the only remaining ground for a revocation in terms of section $164(5)$ in such a scenario.

68 See footnote 3 above.

69 Rule 8 in GN 550 in GG 37819 of 11 July 2014. In terms of rule 9(1)(b), SARS must notify the taxpayer of the allowance or disallowance of the objection and the basis thereof (where SARS requested supporting documents under rule 8 and if the documents were not delivered) within 45 days after the expiry of the period within which the documents must be delivered. This means that after the taxpayer failed to cooperate by not providing the documents, SARS has 45 days to allow or disallow the objection. It could be possible that SARS is still considering the outcome of the objection during this period and wants to revoke the suspension due to noncooperation before allowing or disallowing the objection. 
Table 1: Illustrative example

\begin{tabular}{|c|c|c|c|c|}
\hline 1 & 2 & 3 & 4 & 5 \\
\hline $\begin{array}{l}\text { Factors referred to in } \\
\text { section } 164(3) \text { of the } T A A\end{array}$ & $\begin{array}{l}\text { Decision } \\
\text { to suspend } \\
\text { payment }\end{array}$ & $\begin{array}{l}\text { Material } \\
\text { change in } \\
\text { listed } \\
\text { factor } \\
\text { (scenario } \\
\text { A) }\end{array}$ & $\begin{array}{l}\text { Material } \\
\text { change in } \\
\text { other } \\
\text { factor } \\
\text { (scenario } \\
\text { B) }\end{array}$ & $\begin{array}{l}\text { Possible } \\
\text { ground of } \\
\text { revocation }\end{array}$ \\
\hline $\begin{array}{l}\text { (a) whether the recovery of } \\
\text { the disputed tax will be in } \\
\text { jeopardy or there will be a risk } \\
\text { of dissipation of assets; }\end{array}$ & $\begin{array}{l}\text { No } \\
\text { jeopardy or } \\
\text { risk }\end{array}$ & $\begin{array}{l}\text { Risk of } \\
\text { dissipation } \\
\text { of assets }\end{array}$ & & $\begin{array}{l}\text { Section } \\
164(5)(d) \text { of } \\
\text { the TAA }\end{array}$ \\
\hline $\begin{array}{l}\text { (b) the compliance history of } \\
\text { the taxpayer with SARS; }\end{array}$ & $\begin{array}{l}\text { Good com- } \\
\text { pliance } \\
\text { history }\end{array}$ & & & \\
\hline $\begin{array}{l}\text { (c) whether fraud is prima } \\
\text { facie involved in the origin of } \\
\text { the dispute; }\end{array}$ & No fraud & & & \\
\hline $\begin{array}{l}\text { (d) whether payment will } \\
\text { result in irreparable hardship } \\
\text { to the taxpayer not justified by } \\
\text { the prejudice to SARS or } \\
\text { the fiscus if the disputed tax is } \\
\text { not paid or recovered; or }\end{array}$ & $\begin{array}{l}\text { Irreparable } \\
\text { hardship to } \\
\text { the } \\
\text { taxpayer } \\
\text { not justified } \\
\text { by the } \\
\text { prejudice to } \\
\text { SARS }\end{array}$ & & & \\
\hline $\begin{array}{l}\text { (e) whether the taxpayer has } \\
\text { tendered adequate security } \\
\text { for the payment of the } \\
\text { disputed tax and accepting it } \\
\text { is in the interest of SARS or } \\
\text { the fiscus. }\end{array}$ & $\begin{array}{l}\text { Adequate } \\
\text { security } \\
\text { tendered }\end{array}$ & & & \\
\hline Other relevant factor & & & $\begin{array}{l}\text { Taxpayer is } \\
\text { not } \\
\text { cooperating } \\
\text { with the } \\
\text { objection }\end{array}$ & $\begin{array}{l}\text { Section } \\
164(5)(c) \text { of } \\
\text { the TAA }\end{array}$ \\
\hline
\end{tabular}

In conclusion, and should this suggested application of paragraph (c) be accepted, it is necessary that the grounds for revocation in section 164(5) of the TAA be reconsidered by the legislature. A current reading of paragraph (c) allows for a much wider application, such as a reconsideration 
of information which was already available to the senior SARS official when making the decision to suspend the payment, and which has not materially changed, which is unlikely to withstand constitutional scrutiny.

\subsection{Reasonableness}

The requirement of reasonableness includes inter alia rationality, ${ }^{71}$ which is briefly addressed in the context of a revocation in terms of paragraph (c). Is it possible to take a decision in terms of paragraph (c), as it currently reads, that is rational and accordingly reasonable?

It has been explained in paragraph 3.1.1 above in the context of the functus officio doctrine that a decision taken in terms of paragraph (c) can be regarded as arbitrary and against the interest of legal certainty, as no conditions under which a revocation may take place are provided. A decision that was taken arbitrarily will be reviewable in terms of section $6(2)(e)(v i)$ of PAJA. According to Baxter, "purposeless irrationality of capricious or arbitrary action" is a grave form of unreasonableness. ${ }^{72}$ It can also be said that conduct is arbitrary or capricious "when it is irrational or senseless". ${ }^{73}$ Unreasonableness, irrationality and arbitrariness are thus clearly connected and problematic in the context of paragraph (c).

A further challenge from the senior SARS officials' point of view in this context is how to achieve consistency in the decisions to revoke the suspension in terms of paragraph (c). It has been stated that "tax administration is not seen as arbitrary but transparent". ${ }^{74}$ It may be argued that a decision to revoke in terms of paragraph (c) is arbitrary if the revocation is not done consistently. For example: Some senior SARS officials may decide to "further consider the factors referred to in subsection (3)" on a monthly basis, whereas others do not. The problem is that senior SARS officials currently have no guidance in the TAA on when or how to revoke in terms of paragraph (c), which will inevitably result in inconsistencies. ${ }^{75}$ In order to achieve consistency in the application of paragraph (c), it is possible that SARS has issued internal (unpublished) guidelines. However, there is a fine line between having such guidance to

71 Quinot Administrative Justice 172 and Hoexter Administrative Law 340.

72 Baxter Administrative Law 521. Also see Quinot Administrative Justice 112 where s $6(2)(e)(v i)$ is listed as the ground of review in PAJA corresponding with the requirement of reasonableness.

73 Hoexter Administrative Law 325.

74 Memorandum on the Objects of the Tax Administration Bill, 2011175.

75 SARS Dispute Resolution Guide, 202023 states that there is an obligation on senior SARS officials to "periodically review the suspension - essentially on a risk basis during the dispute process, and to revoke the suspension in the case of dissipation of asset risks or delaying tactics employed by the taxpayer." There is no legal basis for this statement, however. 
achieve consistency or avoiding arbitrariness on the one hand and fettering on the other hand, which should be guarded against. ${ }^{76}$

In Carlson Investments Share Block (Pty) Ltd v Commissioner for SARS, ${ }^{77}$ the court had to determine, inter alia, whether the decision of SARS to revise an assessment (or to re-assess) was arbitrary after an objection to the assessment had been allowed. The court held as follows in respect of arbitrariness:

In my view it is important to understand that the power to re-assess, may only be exercised when the jurisdictional facts set out in $s$ 79(1) are present. This in itself is a brake on the arbitrary exercise of power. If the respondent or any of the respondent's officials were to purport to exercise the power to re-assess in the absence of such jurisdictional facts then such action is clearly challengeable in court.

The challenge is that paragraph (c) provides no such jurisdictional facts to guide the senior SARS official on how and when to exercise his or her discretion to revoke. Pretorius states that a power to revoke must, for the purposes of legal certainty and to avoid arbitrariness, "specify legitimate conditions under which the power of revocation may be exercised". ${ }^{78}$ Such legitimate conditions are absent from paragraph (c).

\subsection{Procedural fairness}

The requirement of procedural fairness is submitted to be especially relevant in the context of a revocation, in the light thereof that this requirement of just administrative action played a much lesser role in the administrative action to suspend the payment. The decision to suspend payment was taken following a request from the taxpayer. This resulted in aspects such as audi alterem partem being complied with automatically by the time the senior SARS official took the decision to suspend the payment. ${ }^{79}$ The same cannot be said for the decision to revoke the suspension in terms of paragraph (c).

In the context of a legislative provision which allows a revocation (such as section 164(5) of the TAA), it should first be determined if the enabling legislation requires a procedure to be followed to revoke a decision. ${ }^{80}$ This is not provided for in the TAA. If no procedure is prescribed, the same procedure as making the original decision should be followed for revoking

\footnotetext{
$76 \quad$ For a more detailed discussion on fettering, see Hoexter Administrative Law 318325; Quinot Administrative Justice 135.

77 Carlson Investments Share Block (Pty) Ltd v Commissioner for SARS 63 SATC 295.

78 Pretorius Functus Officio Doctrine 140.

79 De Lange and Van Wyk 2017 PELJ 19.

80 Pretorius Functus Officio Doctrine 156.
} 
the decision, ${ }^{81}$ but neither does the TAA prescribe a procedure for suspending payment in section 164(3) (the original decision).

Pretorius argues that "the beneficiary of the earlier decision be afforded a hearing before the power of withdrawal or revocation is exercised" in terms of the common law requirements. ${ }^{82}$ This has now been subsumed in PAJA. Section 3(2)(b) of PAJA requires that, in order to give effect to the right to procedurally fair administrative action, the senior SARS official must give the taxpayer (i) adequate notice of the nature and purpose of the proposed administrative action (namely to revoke the suspension of payment), (ii) a reasonable opportunity to make representations, (iii) a clear statement of the administrative action, (iv) adequate notice of any right of review or internal appeal (where applicable) and ( $v$ ) adequate notice of the right to request reasons in terms of section 5 of PAJA.

These requirements of section $3(2)(b)$ of PAJA may be departed from in terms of section 3(4)(a) of PAJA, if it is reasonable and justifiable in the circumstances. ${ }^{83}$ Furthermore, in terms of section 3(5) of PAJA, where an administrator is empowered by any empowering provision to follow a procedure which is fair but different from the requirements listed above, the administrator may act in accordance with that different procedure. In this regard, no procedure for a revocation is provided for in section 164 of the TAA, which means that the requirements of section 3(2)(a) of PAJA should be met when a decision to suspend payment is revoked in terms of paragraph (c). Importantly, the requirements include that the taxpayer must be afforded a reasonable opportunity to make representations before the decision to suspend the payment of disputed tax is revoked. A departure from the requirements should be carefully considered by the senior SARS official in each case, as it would be allowed only in exceptional circumstances. It may, for example, be difficult for a senior SARS official to give the taxpayer adequate notice of the purpose of the revocation if paragraph (c) allows for a reconsideration of information which was already available to the senior SARS official when making the original decision, and which has not materially changed.

$81 \quad$ Pretorius Functus Officio Doctrine 156.

82 Pretorius Functus Officio Doctrine 156.

83 Section $3(4)(b)$ of PAJA lists the following factors to be taken into account in determining whether a departure from the requirements is reasonable and justifiable: (i) the objects of the empowering provision; (ii) the nature and purpose of, and the need to take, the administrative action; (iii) the likely effect of the administrative action; (iv) the urgency of taking the administrative action or the urgency of the matter; and $(v)$ the need to promote an efficient administration and good governance. 
A failure to comply with the requirements of procedural fairness renders the decision to revoke subject to being set aside on review in terms of section 6(2)(c) of PAJA.

\subsection{Requesting reasons}

Section 5(1) of PAJA allows any person whose rights have been materially and adversely affected by administrative action and who has not been given reasons for the action to request, within a certain time limit, that the administrator concerned furnish written reasons for the action. In terms of section 5(2) of PAJA, the administrator to whom the request is made must within a certain time limit give that person adequate reasons in writing for the administrative action.

As mentioned in paragraph 3.3 above, as part of the requirement of procedural fairness, adequate notice of the right to request reasons in terms of section 5 of PAJA must be given by the senior SARS official to the taxpayer when revoking the suspension. However, rather than giving notice of the right to request reasons, De Ville argues that reasons should be provided "where a person's rights are affected through such revocation". ${ }^{84}$ It is therefore prudent for a senior SARS official to give adequate reasons for the decision to revoke the suspension voluntarily, irrespective of whether the taxpayer requests such reasons.

It is submitted that a taxpayer who is dissatisfied with a revocation in terms of paragraph (c) and who has not been provided with reasons for the revocation may request reasons in terms of section 5(1) of PAJA. This taxpayer's rights would have been materially and adversely affected by the revocation as a right which the taxpayer had (not to pay disputed tax in terms of the suspension) is revoked. ${ }^{85}$

It should be noted, however, that a taxpayer would not have been able to request reasons following a lawful, reasonable and procedurally fair decision to suspend the payment of disputed tax (the original decision), as this would have been a decision in favour of the taxpayer. A taxpayer's rights could not have been materially and adversely affected by the original decision and therefore the taxpayer would not necessarily have reasons for the original decision. If a taxpayer requests reasons for the revocation in terms of paragraph (c) (the second decision), it is not clear what the extent of the reasons should be. Would they have to include reasons for the original decision? It could be argued by the senior SARS official that reasons will be provided relating only to the "further consideration" in terms of the second

84 De Ville Judicial Review of Administrative Action 71-72.

85 Hoexter Administrative Law 469-474 considers the argument that the right (which must be materially and adversely affected) can also be the right to administrative justice, which is also applicable in the context of a revocation. 
decision, and not relating to the initial consideration in terms of the original decision. This would make it difficult for a taxpayer to decide whether, and if so how, further action should be taken in respect of the revocation (such as a judicial review thereof), as reasons for the decision to suspend and the decision to revoke do not necessarily have to be provided by the senior SARS official. ${ }^{86}$ This is a concern in the context of a revocation in terms of paragraph (c) and a taxpayer's right to reasons.

\title{
4 Conclusion
}

Should the limited application of paragraph (c) as suggested in paragraph 3.1.3 above be accepted, namely that the material change relates to a factor upon which the decision to suspend was not initially based, it is submitted that paragraphs (c) and (d) should be clarified and integrated into a single ground for revocation. This ground could be formulated as follows:

\begin{abstract}
The senior SARS official referred to in subsection (3) may revoke a decision to suspend payment in terms of subsection (3) with immediate effect if satisfied that there is a material change in any of the factors referred to in subsection (3) and upon further consideration thereof, the suspension should not have been given.
\end{abstract}

The phrase "upon which the decision to suspend payment of the amount involved was based" from the current paragraph (d) should be removed and the phrase "the suspension should not have been given" from the current paragraph (c) should be retained. The latter is necessary although this phrase is not currently included in paragraph (d). Paragraph (d) presently allows for a revocation if there was a material change in any of the factors upon which the decision was made. This should be clarified further to allow for a revocation only if such a change in any of the factors is material enough to warrant a revocation. In other words, the change in the factors should be to such an extent that the suspension would not have been given. At present, paragraph (d) allows for a revocation simply if there was a change in any of the factors. This could result in revocations being unreasonable if the standard of proportionality is not met. ${ }^{87}$ Furthermore, the suggested formulation clarifies that the senior SARS official who granted the

This argument is valid only if the concept of "adequate reasons" does not include the reasons for allowing the suspension, when reasons for revoking the suspension are requested.

87

In the context of revoking a decision in the form of cancelling a licence, De Ville states that this cannot be done when there is a minor breach of the licensing conditions as this would be in conflict with the requirement of proportionality (De Ville Judicial Review of Administrative Action 73). If a breach of conditions for cancelling a licence is equated to a change in factors for revoking a suspension, it is essential that the change in factors must be (i) material and (ii) after further consideration thereof, the suspension should not have been given. Not meeting these requirements could result in a decision which is not proportional and accordingly unreasonable. 
suspension should be the one revoking the decision to suspend payment (see paragraph 3.1.2 above regarding the current uncertainty in this regard). It is submitted that this suggested formulation of a ground for revocation would eliminate the current uncertainties in respect of paragraph (c) and the possibility that revocations in terms thereof are unlawful, unreasonable or procedurally unfair.

It is submitted that these amendments should be considered in order to achieve what the Constitutional Court has held in Dawood $v$ Minister of Home Affairs; Shalabi $v$ Minister of Home Affairs; Thomas $v$ Minister of Home Affairs (hereafter the Dawood case), namely that: ${ }^{88}$

[t]he Legislature must take care when legislation is drafted to limit the risk of an unconstitutional exercise of the discretionary powers it confers.

The Constitutional Court held in the Dawood case that the legislature must, when allowing an administrator to exercise a wide discretionary power, provide guidance on how to exercise the discretion. ${ }^{89}$ This could take the form of listing the circumstances or the factors which are relevant to be taken into account when making a decision. It has been shown that this is absent when a decision is taken in terms of the current paragraph (c). From the viewpoint of the senior SARS official, the current paragraph (c) places "an improperly onerous burden on officials" which should rather be borne by the legislature by providing guidance on when and how to revoke the decision to suspend the payment of disputed tax. ${ }^{90}$

A further peculiar aspect of section 164(5) of the TAA is that paragraphs (a) - (d) serve as grounds to deny a request for a suspension and as grounds to revoke a decision to suspend payment. ${ }^{91}$ It is not clear how the ground of paragraph (c) (which requires "further consideration") can be applicable as a ground for refusal when the request to suspend is being considered. At that point, no suspension has been given. This also applies to paragraph (d) (which requires that there must be a material change in any of the factors referred to in section 164(3) of the TAA upon which the decision to suspend was based). When the request for a suspension is being considered, there is no decision to suspend. It is therefore clear that the wording of section 164(5) of the TAA, and more specifically making it applicable to both denying a request for suspension and revoking a decision to suspend is not ideal. It should be considered by the legislature to split the grounds for

88 Dawood v Minister of Home Affairs; Shalabi v Minister of Home Affairs; Thomas $v$ Minister of Home Affairs 20003 SA 936 (CC) (the Dawood case) para 48.

89 Dawood case para 48 read with Quinot Administrative Justice 99.

$90 \quad$ Dawood case para 50.

91 Section $164(5)$ of the TAA reads as follows: "A senior SARS official may deny a request in terms of subsection (2) or revoke a decision to suspend payment in terms of subsection (3) with immediate effect if satisfied that..." 
denying a request and for revoking a decision to suspend, and to carefully reconsider the grounds upon which a revocation can be made.

The court stated in the Capstone case that the power to reconsider a suspension should exist to ensure that SARS can take speedier decisions regarding a suspension, without the fear of being bound by them. ${ }^{92}$ According to the court, SARS would not be required to conduct "the most careful and conclusive of enquiries into the relevant facts" if it was not committed to the decision to suspend the payment. ${ }^{93}$ It is submitted and concluded, however, that the prejudice which could be suffered by both the taxpayer and the senior SARS official due to an unlawful, unreasonable and/or procedurally unfair revocation should not be at the cost of a speedier outcome of a suspension request.

\section{Bibliography}

\section{Literature}

Baxter Administrative Law

Baxter L Administrative Law (Juta Cape Town 1989)

Croome and Olivier Tax Administration

Croome BJ and Olivier L Tax Administration $2^{\text {nd }}$ ed (Juta Cape Town 2015)

De Lange and Van Wyk 2017 PELJ

De Lange $S$ and Van Wyk D "The Right to Just Administrative Action in the Context of Suspending the Payment of Disputed Tax" 2017 PELJ 1-26

De Ville Judicial Review of Administrative Action

De Ville JR Judicial Review of Administrative Action in South Africa (LexisNexis Durban 2005)

Hoexter Administrative Law

Hoexter C Administrative Law in South Africa $2^{\text {nd }}$ ed (Juta Cape Town 2012)

Pretorius Functus Officio Doctrine

Pretorius DM The Functus Officio Doctrine in South African Administrative Law, with Reference to Analogous Principles in the Administrative Law of Other Commonwealth Jurisdictions (DPhil-thesis University of the Witwatersrand 2004)

Pretorius 2005 SALJ

Pretorius DM "The Origins of the Functus Officio Doctrine, with Specific Reference to its Application in Administrative Law" 2005 SALJ 832-864

\footnotetext{
$92 \quad$ Capstone case para 46.

93 Capstone case para 46.
} 
Pretorius 2006 THRHR

Pretorius DM "The Functus Officio Doctrine and Statutory Authorisation to Vary or Revoke Administrative Acts or Decisions" 2006 THRHR 396-418

Quinot Administrative Justice

Quinot G Administrative Justice in South Africa: An Introduction (Oxford University Press Cape Town 2015)

SARS Dispute Resolution Guide, 2020

South African Revenue Service Dispute Resolution Guide: Guide on the Rules Promulgated in terms of Section 103 of the Tax Administration Act, 2011 (SARS Pretoria 2020)

SARS Short Guide to the TAA, 2011

South African Revenue Service Short Guide to the Tax Administration Act, 2011 (SARS Pretoria 2018)

Van Wyk and Van Zyl 2016 JEF

Van Wyk D and Van Zyl L "An Analysis of the Relevancy of the Factors Considered Following a Request for the Suspension of the Payment of Disputed Tax in terms of Section 164(3) of the Tax Administration Act 28 of 2011" 2016 JEF 561-577

Case law

Capstone 556 (Pty) Ltd v Commissioner for SARS 74 SATC 20

Carlson Investments Share Block (Pty) Ltd v Commissioner for SARS 63 SATC 295

Commissioner for SARS v Miles Plant Hire (Pty) Ltd 76 SATC 1

Dawood v Minister of Home Affairs; Shalabi v Minister of Home Affairs;

Thomas $v$ Minister of Home Affairs 20003 SA 936 (CC)

Metcash Trading Ltd v Commissioner for SARS 63 SATC 13

\section{Legislation}

Constitution of the Republic of South Africa, 1996

Customs and Excise Act 91 of 1964

Customs and Excise Amendment Act 32 of 2014

Customs Control Act 31 of 2014

Income Tax Act 58 of 1962

Promotion of Administrative Justice Act 3 of 2000

Tax Administration Act 28 of 2011 
Tax Administration Laws Amendment Act 21 of 2012

Tax Administration Laws Amendment Act 39 of 2013

Tax Administration Laws Amendment Act 44 of 2014

Value-Added Tax Act 89 of 1991

\section{Government publications}

GN 550 in GG 37819 of 11 July 2014

\section{Internet sources}

SARS 2011 https://www.sars.gov.za/AllDocs/LegalDoclib/ExplMemo /LAPD-LPrep-EM-2011-03\%20-\%20Memorandum\%20Objects\%20Tax\% 20Administration\%20Bill\%202011.pdf

South African Revenue Service 2011 Memorandum on the Objects of the Tax Administration Bill, 2011 https:/www.sars.gov.za/AllDocs/Legal Doclib/ExpIMemo/LAPD-LPrep-EM-2011-03\%20-\%20Memorandum\%20 Objects\%20Tax\%20Administration\%20Bill\%202011.pdf accessed 24 January 2021

\section{List of Abbreviations}

JEF

PAJA

PELJ

SALJ

SARS

TAA

THRHR

VAT
Journal of Economic and Financial Services

Promotion of Administrative Justice Act 3 of 2000

Potchefstroom Electronic Law Journal

South African Law Journal

South African Revenue Service

Tax Administration Act 28 of 2011

Tydskrif vir Hedendaagse Romeins-Hollandse Reg Value-added tax 